\title{
FACTORS INFLUENCE STUDENT SATISFACTION IN PHARM EDUCATION PROGRAM: A CASE STUDY IN PRIVATE UNIVERSITIES IN VIETNAM
}

\author{
FATORES QUE INFLUENCIAM A SATISFAÇÃO DO ALUNO NO PROGRAMA DE \\ EDUCAÇÃO FARMACÊUTICA: UM ESTUDO DE CASO EM UNIVERSIDADES \\ PRIVADAS NO VIETNA
}

\author{
FACTORES QUE INFLUYEN EN LA SATISFACCIÓN DE LOS ESTUDIANTES EN EL \\ PROGRAMA DE EDUCACIÓN FARMACÉUTICA: UN ESTUDIO DE CASO EN \\ UNIVERSIDADES PRIVADAS EN VIETNAM
}

\author{
Nguyen Thanh NGHIA ${ }^{1}$ \\ Harwindar SINGH ${ }^{2}$
}

\begin{abstract}
In the Industrial Revolution 4.0 (IR 4.0), the role of higher education (HE) stays crucial for the development of highly skilled human resources in the multi-service sector. Indeed, the pharmaceutical education quality in higher education is significant for building a quality workforce in the healthcare service sectors. Additionally, the increasingly global education market required the ongoing increase of quality in higher education. This study investigates the driving factors of student satisfaction in Pharmacy education at private universities in Vietnam. Both qualitative and quantitative approaches are used in this study. For quantitative research, the surveyed questionnaire is developed and is the primary instrument. Besides, focus groups, semi-structured in-depth interviews with experts, and meta-analysis are applied instruments for qualitative research. The sample is 265 students from 3 private universities. The driving factors of student satisfaction are (1) Educational program, (2) University Reputation, (3) Business Interaction, (4) Extracurricular activities, and (5) Teaching facilitators activities. Eventually, the authors propose the suggestions for both academic and practical perspectives; simultaneously, the limitation is discussed for further research.
\end{abstract}

KEYWORDS: Service quality. Higher education. Performance measurement (quality). Pharmacy.

RESUMO: Na Revolução Industrial 4.0 (RI 4.0), o papel do ensino superior (ES) permanece crucial para o desenvolvimento de recursos humanos altamente qualificados no setor de multisserviços. De fato, a qualidade da educação farmacêutica no ensino superior é significativa para a construção de uma força de trabalho de qualidade nos setores de serviços de saúde. Além disso, o mercado de educação cada vez mais global exige o aumento contínuo da qualidade do ensino superior. Este estudo investiga os fatores que impulsionam a satisfação dos alunos no ensino de Farmácia em universidades privadas no Vietnã. Tanto a abordagem qualitativa quanto a quantitativa são utilizadas neste estudo. Para pesquisas quantitativas, o questionário pesquisado é desenvolvido e é o principal instrumento. Além disso, grupos focais, entrevistas semiestruturadas em profundidade com especialistas e metaanálises são instrumentos aplicados para a pesquisa qualitativa. A amostra é de 265 alunos

${ }^{1}$ Malaysia University of Science and Technology (MUST), Petaling Jaya - Malaysia. Ph.D. Student, Department of Management. ORCID: https://orcid.org/0000-0001-5466-8418. E-mail: ntnghia61@yahoo.com

${ }^{2}$ Malaysia University of Science and Technology (MUST), Petaling Jaya - Malaysia. Ph.D. School of Business. ORCID: https://orcid.org/0000-0002-8586-7951. E-mail: drharwindar@must.edu.my 
de 3 universidades privadas. Os fatores que impulsionam a satisfação do aluno são (1) Programa educacional, (2) Reputação universitária, (3) Interação nos negócios, (4) Atividades extracurriculares e (5) Atividades de facilitadores de ensino. Eventualmente, os autores propõem as sugestões para perspectivas acadêmicas e práticas; simultaneamente, a limitação é discutida para pesquisas futuras.

PALAVRAS-CHAVE: Qualidade do serviço. Ensino superior. Medição de desempenho (qualidade). Farmácia.

RESUMEN: En la Revolución Industrial 4.0 (IR 4.0), el papel de la educación superior (ES) sigue siendo crucial para el desarrollo de recursos humanos altamente calificados en el sector multiservicio. De hecho, la calidad de la educación farmacéutica en la educación superior es importante para construir una fuerza laboral de calidad en los sectores de servicios de salud. Además, el mercado de la educación cada vez más global requiere el aumento continuo de la calidad en la educación superior. Este estudio investiga los factores impulsores de la satisfacción de los estudiantes en la educación de farmacia en universidades privadas en Vietnam. En este estudio se utilizan enfoques tanto cualitativos como cuantitativos. Para la investigación cuantitativa, el cuestionario encuestado se desarrolla y es el instrumento principal. Además, los grupos focales, las entrevistas en profundidad semiestructuradas con expertos y el metanálisis son instrumentos aplicados para la investigación cualitativa. La muestra es de 265 estudiantes de 3 universidades privadas. Los factores que impulsan la satisfacción de los estudiantes son (1) Programa educativo, (2) Reputación universitaria, (3) Interacción empresarial, (4) Actividades extracurriculares y (5) Actividades de facilitadores docentes. Finalmente, los autores proponen las sugerencias tanto para perspectivas académicas como prácticas; simultáneamente, la limitación se discute para futuras investigaciones.

PALABRAS CLAVE: Calidad del servicio. Educación superior. Medición del desempeño (calidad). Farmacia.

\section{Introduction}

Today, humankind is involved in a radical transformation of the Industrial Revolution 4.0 (hereinafter referred to as IR 4.0), in which developments and uncertainties coexist. Indeed, the negative impact of the global pandemic COVID-19 creates an unprecedented threat in humankind's society that exhausts the healthcare system in nations. Additionally, universities have made great efforts to support the healthcare system in coping with critical circumstances; simultaneously, the far-sighted objectives are attained to shape the further development of education in healthcare sectors (BASHETI et al., 2021). Hence, a study in Australia's higher education, the pharmaceutical education program is adjusted by adding vaccination training and practices in the Bpharm's curriculum since epidemic prevention is a crucial factor for the safeness of human civilization (BUSHELL et al., 2019). Apart from that, 
a pharmacist creates an influence on patients' psychological state and pharmaceutical education (BASHETI et al., 2021). Primarily, the perceived role of the professional pharmacist is associated with pharmaceutical care, such as effectively providing medications (ABUSHAM; AL-HARTHY, 2018). Regardless of the importance, pharmacists' performance is distinctively reflected in developing countries following the educational level; for instance, a distinctive gap is perceived between university and college students in pharmacy education (NGUYEN; DINH; NGUYEN, 2021). Indeed, in IR 4.0 era, the global market is required the increasing quality of human resources in most industries; hence, the higher education role is reconciled, which greatly influences the transformation. Significantly, the quality of Pharmacy education is perceived as one of the significant for the substantial development of a healthcare system. As a result, higher education institutions are interrelated to enhancing educational quality, whereby student satisfaction is accepted as the influential factor (ELLIOTT, 2002; TANDILASHVILI, 2019). The increasing impact of student satisfaction is due to the concept of service implication in higher education, which is associated with customer-centric or customer-driven orientations. Accordingly, students are conceived as crucial stakeholders of higher education service, whereupon students' needs and desires are prioritized to fulfill. Also, higher education is driven by marketization and globalization, in which the competition among educational institutions is rapidly elevated. As such, student satisfaction is afforded considerable research concerns academically and practically in the responsiveness of changing market demand (TESSEMA; READY; YU, 2012). Also, BPharm students' feedback is related to strengthening educational quality in Pharmacy Program (ABUSHAM; AL-HARTHY, 2018).

In Vietnam, a surging establishment of private universities results in intensified competition in higher education due to the government's socializing education policy. In this circumstance, higher education institutions (hereinafter referred to as HEIs) strive to build up competitiveness to survive the competition (TRUONG; PHAM; VO, 2016; DOAN, 2021). Hence, universities strive to create significant investment into infrastructure, concurrently redefining the quality term following student-centric orientation. Furthermore, private universities make a crucial investment in multi-facets, aiming to satisfy the current students and persuade the potential students. The development of private universities offers more educational opportunities students, also raise quality concern for key stakeholders (i.e., government, researchers, and parents). Significantly, higher education quality and its relatedness are analyzed in studies, from which suggestions and recommendations are proposed to enhance the performance of higher education institutions. For Pharmacy 
education in Vietnam, 5 primary career prospects are recognized, including management and distribution of medicine, medical innovation and processing, clinical pharmaceutical practitioners, traditional medicine, and quality control in pharmacy (VO et al., 2013). Additionally, Vo et al. (2013) depict that a qualified pharmacist is required to have a university degree or higher, and a standard university curriculum for pharmacy is 5-year fulltime. In studies, higher student satisfaction is analyzed (TRUONG; PHAM; VO, 2016; PHAM et al., 2019; CHEN; CUONG, 2020); however, limited studies focus on the student's satisfaction with BPharm in private universities. Therefore, this study's focus depicts student satisfaction in Pharmacy programs at private universities. For contribution, the authors aim to propose the improvement for the educational quality of BPharm education. Nonetheless, this paper creates a contribution to the knowledge of tertiary education quality.

\section{Literature reviews}

\section{Quality in higher education}

In a different context, the notion of quality is determined differently, including purpose fitness, reliability, sustainability, aesthetics, etc.; as a result, quality is accepted as a complex and multi-dimensional concept (BOGUE, 1998). According to Ngoc (2008), the attainment of objectives that fulfill societal development. Furthermore, the notion of quality is associated with exceptional, error-free, and the fitness of customer's preference, standard, value for money, and ongoing improvement and innovation (TRAN; LEWIS, 2012). Hence, in higher education, the fitness of objective in building up social responsibility awareness is associated with quality evaluation (BRUBACHER 1982; CHINH, 2000). Besides, higher education quality is interpreted as a process of knowledge creation and transfer, whereupon producing quality human resources for the improvement of the global workforce (MALCOLM, 1994; LEE, 2017). Accordingly, fitness for educational objectives is accepted as the primary consideration for students, in which the improvement in knowledge, skills, and attitudes are determined factor quality in higher education (KILOVA, 2020). Significantly, fulfillment of students' needs and desire for development crucially impacts the quality of universities. Indeed, the educational quality relies on the students' preference and evaluation since a satisfied student is fulfilled by objectives and is perceived as a university's efforts (WANG; SUN; JIANG, 2018). Furthermore, the performance of the workforce is used as the evaluative criteria for higher education; however, this evaluation might have been overestimated since the workforce performance is also accepted the influenced by other 
factors. In a study by Bogue and Saunder (1992), quality is defined by acceptable standards regarding public evaluation and affirmation, which is depicted by the universities mission statement and attainable objectives. Thus, the concept of a high-quality university is interconnected with the determined mission statement and quality-driven objectives, which greatly influence the output performance (GREEN, 1994). In Vietnam, the quality of graduate students is required to achieve ethics, knowledge, skill comprehension, and proper attitudes, in turn determining the higher education quality. Indeed, the quality of higher education is still product-oriented appreciation in Vietnamese society (TRUONG; PHAM; VO, 2016). As per the concept, quality is related to the output of the educational process and is determined by learners' capability in the workplace. In line with that, higher education has the excellent quality, consistency, and perfection; objective fitness; value for money; transformation value; and value-added creation (HARVEY; GREEN, 1993). Therefore, the transformation of higher education quality is accepted from elite to broad-based perspective (TURNER, 2011).

\section{Concept of Student Satisfaction}

As known, higher education quality is related to various stakeholders' perspectives, including students, parents, teachers, and employers (CHUA, 2004). Of which assertion, students are conceived as a key stakeholder who is perceived differently from a commercial service customer (KAMVOUNIAS, 1999). In studies, the positive correlation between service quality and satisfaction of customers is determined in various sectors (DE RUYTER et al., 1997; BRADY; ROBERTSON, 2001). In relation to the mentioned point, Aga and Safakli, (2007) confirm that customer satisfaction is exerted by service quality, company image, and service price. Indeed, customer satisfaction is ascribed as an individual's sensory state referring to the difference between purchased products (i.e., goods and/or services) and predetermined expectations (KOTLER, 2001). The predetermined expectations consume the influence from personal needs, prior experience, and external information sources (i.e., advertising, family and friends, internet, etc.). Additionally, customers' responsiveness toward the difference between requisite expectation and actual receive crucially influences satisfaction level (TSE; WILTON, 1988). More of that, Brown (1992) asserts that customer satisfaction is connected to individuals' needs, wants, and expectations, which is explicated by positive satisfaction when the post-purchased value exceeds the requisite expectation; as a result, repurchase, customer loyalty, and better word-of-mouth is recognized. In line with that, customer satisfaction relied on the level of needs fulfillment regarding a specific product 
and/or service (ZEITHAML; BITNER, 2000). Thus, the concept of customer satisfaction is restricted to individual viewpoints. Therefore, the affirmed contribution of customer satisfaction is to build up enterprise competitiveness by influencing service quality, so forth customer loyalty.

\section{The HEdPERF model of quality measurement}

As the above discussion, student satisfaction is crucially perceived as one of the influential factors driving educational service quality. Also, along with service sectors development, many models are constructed and applied to measure the multi-facets of service, including the SERVQUAL model, SERVPERF, and HEdPERF. Hence, SERVQUAL is developed by Parasuraman, Zeithaml and Berry (1988), and the model depicts the concept of quality in five dimensions of service firm and unfolds the five service gaps. By adapting the SERVQUAL conceptual framework, Cronin and Taylor (1992) assert the better measurement scale, which is accepted as a performance-driven approach. Both SERVQUAL and SERVPERF have analyzed a service firm in five dimensions following (1) Empathy, (2) responsiveness, (3) Trust, (4) Tangibilitie, (5) Service capacity following the SERVQUAL model. In studies, the two models are applied in measuring the educational quality of educational institutions (SNIPES; THOMSON, 1999; LONG 2006; KIEN, 2008; LUONG, 2011). However, in higher education, limitations are unfolded in the models that the improvement of findings raises the research concerns, leading to the further development known as HEdPERF. Indeed, HEdPERF is purposefully developed to measure the quality of higher education, which is perceived to offer a better measurement scale including 6 dimensions and 41 components (ABDULLAH, 2006a). According to Abdullah (2006b) higher education is accepted as a sophisticated service that necessitates performance-driven measurement, whereby the inclusion of non-academic and academic assessment is considered crucial. Accordingly, the HEdPERF indicates 6 dimensions, including (D1) non-academic aspects (i.e., student life, student support service, career counseling, etc.); (D2) academic aspects (i.e., curriculum, academic references, academic supports, etc.); (D3) Reputation (i.e., university ranking, achievement, high graduate employment rate, etc.); (D4) Access (i.e., availability of service, convenient campus, modern facilities, etc.); (D5) Program issue (i.e., lesson structure, knowledge delivery, updated content, etc.); (D6) Understanding (i.e., analysis of students' needs, empathize with students, wholehearted supports for student, etc.). In studies, the HEdPERF model is accepted as suitable for higher education quality 
measurement (ABDULLAH, 2006b; KHALID; ALI; MAKHBUL, 2019). Therefore, the HEdPERF framework is adapted to direct the determining factors that influence student satisfaction in this study.

\section{Factors affecting student satisfaction}

\section{Educational program}

In education, the quality of the educational program is perceived as the influential determinant which indicates the teaching approaches, content, and expected outcomes (DI GREGORIO; BEATON, 2019). Accordingly, the educational program is connected with a student learning experience, from which students evaluate the worth for the study program, resulting in high/low satisfaction levels (KIRMIZI, 2015). Therefore, the attractive educational program has an influence on student satisfaction.

H1: Educational program influences BPharm student satisfaction on educational quality

\section{University reputation}

University reputation is connected to various elements, including image, ranking, and educational program. Indeed, universities strive to build a preferable image that attracts more students and enhances student satisfaction towards universities (OSMAN, \& SAPUTRA, 2019). Also, According to Djafri, Meguellati \& Omar (2013), service quality and institution image are interconnected, and the positive image results in increased student loyalty.

H2: University reputation impacts Bpharm student satisfaction with the educational quality

\section{Business interaction}

Business interaction is accepted as an influential factor for higher education since the collaboration with business benefices educational institutions in various aspects (NECHEUKHINA et al., 2017). For instance, internship arrangement, professional consultancy, and employment insight are perceived as significant for both sides. Pharmacy education, practicum, and/or clinical internship in a hospital, pharmaceutical company/organization are significant for pharmaceutical students and are the compulsory condition before becoming a qualified pharmacist (VO et al., 2013). Hence the business 
interaction influences student satisfaction with educational quality. According to Necheukhina et al. (2017), the interaction between business and educational institutions provides the student with practical engagement and career prospect development.

H3: Business interaction influences BPharm student satisfaction with the educational quality

\section{Extracurricular activities}

As known, the formal curriculum provides the student with academic knowledge and skills. Besides, students are encouraged to develop more life skills, employability skills, and social skills by participating in extracurricular activities. In a study, Letcher \& Neves (2010) confirms that extracurricular activities are appreciated by higher education students and have a crucial contribution to increased student satisfaction. Additionally, extracurricular activities are the contributors to students' encouragement in studying, resulting in better academic performance and satisfaction (BAKOBAN; ALJARALLAH, 2015).

H4: Extracurricular activities influences Bpharm student satisfaction with the educational quality

\section{Teaching facilitators quality}

According to studies, teaching facilitators' roles are recognized as significant elements of higher education quality. Teaching facilitators are primarily engaging in supporting student self-development. Indeed, the quality of the lecturer is related to the distinctiveness in pedagogical approaches and professional knowledge and is effectively transmitting knowledge to the student. As such, the relationship between lecturer quality and educational quality in higher education is confirmed (SAVAGE; BIRCH; NOUSSI, 2011; GIAO; LIEN, 2021)

H5: Teaching facilitator impacts BPharm student satisfaction with the educational quality

\section{The proposed research model}

As above depiction, the authors propose five independent factors influencing on BPharm student satisfaction with educational quality, including (1) Educational program, (2) Universities reputation, (3) Business interaction of universities, (4) Extracurricular activities, 
and (5) teaching facilitator quality. As such, the authors proposed the research model as follows.

Figure 1 - The proposed model

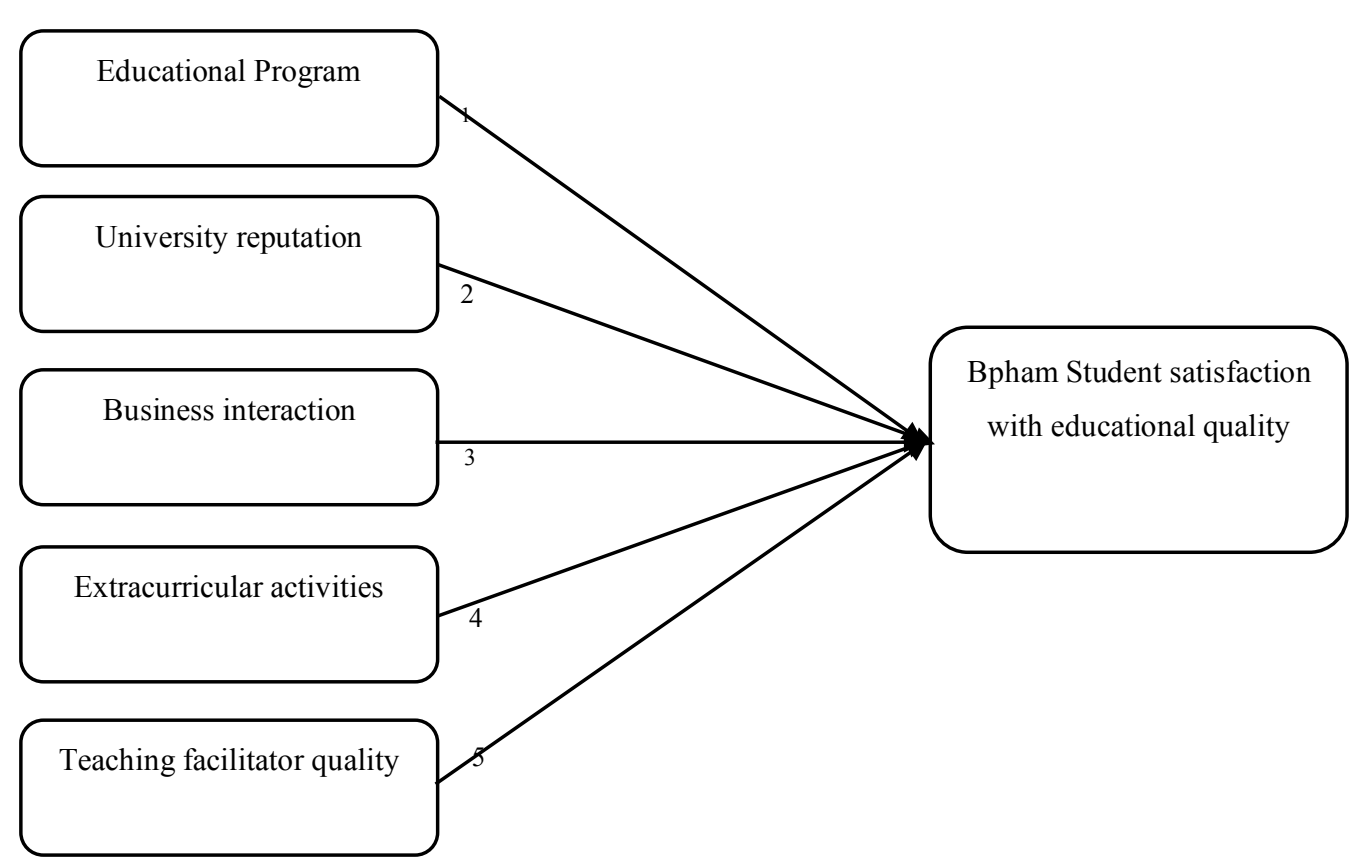

Source: Prepared by the authors

\section{Methodology}

The study is applied both qualitative and quantitative research methods for collecting primary and secondary data. For the qualitative research, the authors have done 3 focus groups and 7 in-depth interviews with experts from Medicine and Pharmacy Faculty in different universities, who are the Dean/Unit-Chair/Senior Lecturers. As a result, the authors strive to unearth pharmaceutical education's outlooks and probe deeply to uncover the underlying knowledge. Furthermore, the authors randomly interview 20 students from 3 universities, who are pharmaceutical students, to acknowledge the students' viewpoints upon educational quality. For the quantitative approach, authors develop a questionnaire for survey research by adapting from previous studies (TRAN; LEWIS, 2012; LE, 2015; LIEN, 2016; VIET, 2017), significantly, the draft questionnaire is submitted to university professor for revision, and minor adjustment is made. For readability and understandability, the authors have conducted the pilot test with 10 students, and as a result, the questionnaire is highly readable and understandable. Following that, the questionnaires that have been administered received 269 responses (96.4\%), from which 265 valid responses are determined after 
excluding invalid responses. And valid data has been processed for analysis using SPSS version 22 .

\section{Findings and Discussion}

According to the result, 137(51.70\%) female participants have been recognized, whereas 128 male participants (48.31\%) are involved. Additionally, the distribution of students regarding year-of-learning is at a low variant; indeed, the $4^{\text {th }}$ year and $2^{\text {nd }}$ year students are most recognized in this sample size. Additionally, the study has been conducted in 3 private universities in Ho Chi Minh City, including Ho Chi Minh City University of Technology (HUTECH), Nguyen Tat Thanh University (NTTU), and Hong Bang University (HBU).

Table 1 - Sample Characteristic

\begin{tabular}{|c|c|c|}
\hline & Count & Ratio \\
\hline Gender & $\mathrm{N}=\mathbf{2 6 5}$ & $100 \%$ \\
\hline Male & 128 & 48.31 \\
\hline Female & 137 & 51.70 \\
\hline Year of learning & $\mathrm{N}=\mathbf{2 6 5}$ & $100 \%$ \\
\hline $1^{\text {st }}$ year & 57 & 21.5 \\
\hline $2^{\text {nd }}$ year & 48 & 18.12 \\
\hline $3^{\text {rd }}$ year & 63 & 23.78 \\
\hline $4^{\text {th }}$ year & 70 & 26.42 \\
\hline $5^{\text {th }}$ year & 27 & 10.19 \\
\hline Educational Institution & $\mathrm{N}=\mathbf{2 6 5}$ & $100 \%$ \\
\hline HUTECH & 85 & 32.08 \\
\hline NTTU University & 110 & 41.51 \\
\hline Hong Bang University & 70 & 26.42 \\
\hline
\end{tabular}

Source: Prepared by the authors

Table 2 - Cronchbach alpha results

\begin{tabular}{|c|c|c|c|c|}
\hline Items & $\begin{array}{l}\text { Scale Mean if } \\
\text { Item Deleted }\end{array}$ & $\begin{array}{l}\text { Scale Variance } \\
\text { if Item Deleted }\end{array}$ & $\begin{array}{c}\text { Corrected Item- } \\
\text { Total } \\
\text { Correlation }\end{array}$ & $\begin{array}{c}\text { Cronbach's } \\
\text { Alpha if Item } \\
\text { Deleted }\end{array}$ \\
\hline Teaching Facilitator $\mathrm{C}$ & & & \multicolumn{2}{|c|}{ Cronbach alpha $=.892$} \\
\hline TQ1 & 25.77 & 69.314 & .686 & .892 \\
\hline TQ2 & 25.81 & 70.393 & .683 & .893 \\
\hline TQ3 & 26.09 & 69.438 & .670 & .894 \\
\hline TQ4 & 25.76 & 70.880 & .671 & .893 \\
\hline TQ5 & 25.83 & 71.028 & .654 & .895 \\
\hline TQ6 & 26.01 & 69.806 & .663 & .894 \\
\hline
\end{tabular}

RPGE- Revista on line de Política e Gestão Educacional, Araraquara, v. 25, n. 3, p. 2611-2630, Sep./Dec. 2021. e-ISSN: 1519-9029 DOI: https://doi.org/10.22633/rpge.v25i3.15844 


\begin{tabular}{|c|c|c|c|c|}
\hline TQ7 & 25.93 & 69.775 & .688 & .892 \\
\hline TQ8 & 25.97 & 69.669 & .661 & .894 \\
\hline TQ9 & 25.95 & 69.892 & .709 & .891 \\
\hline \multicolumn{3}{|l|}{ Educational Program } & \multicolumn{2}{|c|}{ Cronbach alpha $=.856$} \\
\hline ED1 & 15.882 & 25.320 & .761 & .879 \\
\hline ED2 & 15.854 & 26.619 & .558 & .867 \\
\hline ED3 & 15.799 & 26.052 & .612 & .834 \\
\hline ED4 & 15.843 & 27.513 & .639 & .879 \\
\hline ED5 & 15.882 & 26.783 & .762 & .828 \\
\hline ED6 & 15.882 & 25.238 & .761 & .795 \\
\hline \multicolumn{3}{|l|}{ Business Interaction } & \multicolumn{2}{|c|}{ Cronbach alpha $=.841$} \\
\hline BI1 & 13.26 & 15.725 & .657 & .806 \\
\hline $\mathrm{BI} 2$ & 13.28 & 16.137 & .646 & .809 \\
\hline $\mathrm{BI} 3$ & 13.33 & 16.022 & .653 & .807 \\
\hline $\mathrm{BI} 4$ & 13.23 & 16.073 & .629 & .814 \\
\hline BI5 & 13.28 & 16.148 & .643 & .810 \\
\hline \multicolumn{3}{|l|}{ University reputation } & \multicolumn{2}{|c|}{ Cronbach alpha $=.836$} \\
\hline UR1 & 14.22 & 15.222 & .638 & .803 \\
\hline UR2 & 14.16 & 15.452 & .664 & .796 \\
\hline UR3 & 14.24 & 15.460 & .635 & .804 \\
\hline UR4 & 14.09 & 15.313 & .685 & .790 \\
\hline UR5 & 14.24 & 16.027 & .568 & .822 \\
\hline \multicolumn{3}{|c|}{ Extracurricular activities } & \multicolumn{2}{|c|}{ Cronbacj alpha $=.919$} \\
\hline EX1 & 17.82 & 29.508 & .780 & .903 \\
\hline EX2 & 17.97 & 29.889 & .772 & .904 \\
\hline EX3 & 17.85 & 29.818 & .752 & .907 \\
\hline EX4 & 17.81 & 29.667 & .760 & .906 \\
\hline EX5 & 17.96 & 29.699 & .777 & .903 \\
\hline EX6 & 17.91 & 30.092 & .776 & .904 \\
\hline \multicolumn{3}{|c|}{ BPharm Student satisfaction with educational program } & \multicolumn{2}{|c|}{ Cronchbach alpha $=.871$} \\
\hline SS1 & 17.12 & 24.058 & .661 & .851 \\
\hline SS2 & 16.97 & 23.596 & .734 & .839 \\
\hline SS3 & 17.14 & 23.979 & .727 & .840 \\
\hline SS4 & 17.07 & 24.583 & .605 & .861 \\
\hline SS5 & 17.13 & 23.951 & .615 & .860 \\
\hline SS6 & 17.17 & 24.012 & .699 & .845 \\
\hline
\end{tabular}

Source: Prepared by the authors

As a result, 31 observed variables are eligible for EFA processing. Due to the second EFA results, all 29 observed variables depict five factors at the Eigenvalue $=1.250$, with an average extracted variance is $58.643 \%(>50 \%)$. Also, the KMO is .912 with the sig value is .000 , of which the strong correlation with the data set is confirmed. Moreover, all the 
observed variables return to the predetermined group following the variable summary after the second EFA.

Table 3 - Sampling Adequacy result

\section{KMO and Bartlett's Test}

Kaiser-Meyer-Olkin Measure of Sampling Adequacy.

Bartlett's Test of Sphericity

Approx. Chi-Square

df

Source: Prepared by the authors

Table 4 - EFA result

\begin{tabular}{|c|c|c|c|c|c|}
\hline & \multicolumn{5}{|c|}{ Component } \\
\hline Item & 1 & 2 & 3 & 4 & 5 \\
\hline TQ1 & .826 & & & & \\
\hline TQ3 & .767 & & & & \\
\hline TQ2 & .731 & & & & \\
\hline TQ5 & .716 & & & & \\
\hline TQ8 & .707 & & & & \\
\hline TQ9 & .694 & & & & \\
\hline TQ6 & .671 & & & & \\
\hline BI5 & & .780 & & & \\
\hline BI3 & & .737 & & & \\
\hline BI2 & & .695 & & & \\
\hline BI1 & & .668 & & & \\
\hline BI4 & & .665 & & & \\
\hline EX5 & & & .843 & & \\
\hline EX2 & & & .812 & & \\
\hline EX3 & & & .807 & & \\
\hline EX1 & & & .800 & & \\
\hline EX4 & & & .796 & & \\
\hline EX6 & & & .796 & & \\
\hline UR1 & & & & .753 & \\
\hline UR2 & & & & .728 & \\
\hline UR3 & & & & .693 & \\
\hline UR5 & & & & .669 & \\
\hline UR4 & & & & .653 & \\
\hline ED1 & & & & & .818 \\
\hline ED3 & & & & & .775 \\
\hline ED6 & & & & & .771 \\
\hline ED2 & & & & & .757 \\
\hline ED5 & & & & & .733 \\
\hline ED3 & & & & & .723 \\
\hline
\end{tabular}

Source: Prepared by the authors

RPGE- Revista on line de Política e Gestão Educacional, Araraquara, v. 25, n. 3, p. 2611-2630, Sep./Dec. 2021. e-ISSN: 1519-9029 DOI: https://doi.org/10.22633/rpge.v25i3.15844 
As the Correlation analysis results, all the factors have a significant correlation with the dependent variables. Moreover, all the independent variables have no correlation; therefore, none of multi-collinearity might have occurred. The result is indicated in Table 5.

Table 5 - Correlation analysis

\begin{tabular}{|c|c|c|c|c|c|c|c|}
\hline & & SS & TQ & BI & EX & UR & ED \\
\hline \multirow[t]{3}{*}{$\mathbf{S}$} & Pearson Correlation & 1 & $659^{* *}$ & $639^{* *}$ & $614^{* *}$ & $754^{* *}$ & $724^{* *}$ \\
\hline & Sig. (2-tailed) & & 000 & 000 & 000 & 000 & 000 \\
\hline & $\mathrm{N}$ & $\begin{array}{ll} & 2 \\
65 & \end{array}$ & $\begin{array}{ll} & 2 \\
65 & \end{array}$ & $\begin{array}{ll} & 2 \\
65 & \end{array}$ & $\begin{array}{ll} & 2 \\
65 & \end{array}$ & $\begin{array}{ll} & 2 \\
65 & \end{array}$ & 65 \\
\hline \multirow[t]{3}{*}{$\mathbf{Q}$} & Pearson Correlation & $659^{* *}$ & 1 & $424^{* *}$ & $510^{* *}$ & $564^{* *}$ & $523^{* *}$ \\
\hline & Sig. (2-tailed) & 000 & & . & 000 & 000 & 000 \\
\hline & $\mathrm{N}$ & $\begin{array}{ll} & 2 \\
65 & \end{array}$ & 65 & 65 & $\begin{array}{ll} & 2 \\
65 & \end{array}$ & 65 & 65 \\
\hline \multirow[t]{3}{*}{$\mathbf{I}$} & Pearson Correlation & $639^{* *}$ & $424^{* *}$ & 1 & $437^{* *}$ & $558^{* *}$ & $546^{* *}$ \\
\hline & Sig. (2-tailed) & 000 & 000 & & 000 & 000 & 000 \\
\hline & $\mathrm{N}$ & $\begin{array}{ll} & 2 \\
65 & \end{array}$ & 65 & 65 & 65 & 65 & 65 \\
\hline \multirow[t]{3}{*}{$\mathbf{X}$} & Pearson Correlation & $614^{* *}$ & $510^{* *}$ & $437^{* *}$ & 1 & $470^{* *}$ & $513^{* *}$ \\
\hline & Sig. (2-tailed) & 000 & 000 & 000 & & 000 & 000 \\
\hline & $\mathrm{N}$ & $\begin{array}{ll} & 2 \\
65 & \end{array}$ & 65 & 65 & 65 & 65 & 65 \\
\hline \multirow[t]{3}{*}{$\mathbf{R}$} & Pearson Correlation & $754^{* *}$ & $564^{* *}$ & $558^{* *}$ & $470^{* *}$ & 1 & $662^{* *}$ \\
\hline & Sig. (2-tailed) & 000 & 000 & 000 & 000 & & 000 \\
\hline & $\mathrm{N}$ & 65 & 65 & 65 & 65 & 65 & 65 \\
\hline \multirow[t]{3}{*}{ D } & Pearson Correlation & $724^{* *}$ & $523^{* *}$ & $546^{* *}$ & $513^{* *}$ & $662^{* *}$ & 1 \\
\hline & Sig. (2-tailed) & 000 & 000 & 000 & 000 & 000 & \\
\hline & $\mathrm{N}$ & 2 & 2 & 2 & 2 & 2 & 2 \\
\hline
\end{tabular}




\begin{tabular}{|l|l|l|l|l|l|l|l|}
\hline & 65 & 65 & 65 & 65 & 65 & 65 \\
\hline
\end{tabular}

Source: Prepared by the authors

Table 6 - ANNOVA

\begin{tabular}{|r|c|c|c|c|c|}
\hline Model & $\mathrm{R}$ & & & Std. Error of the Estimate & Durbin-Watson \\
\hline 1 & $799^{\mathrm{a}}$ & 638 & 628 & .44409 & 2.069 \\
\hline & & & & & \\
\hline
\end{tabular}

Source: Prepared by the authors

Table 7 - Regression Summary

\begin{tabular}{|c|c|c|c|c|c|c|}
\hline \multicolumn{2}{|c|}{ Model } & Sum of Square & f & Mean Square & F & ig. \\
\hline & Regression & 86.462 & & 12.352 & 62.630 & $000^{\mathrm{b}}$ \\
\cline { 2 - 7 } & Residual & 49.107 & 49 & .197 & & \\
\cline { 2 - 7 } & Total & 135.570 & 56 & & & \\
\hline
\end{tabular}

Source: Prepared by the authors

Table 8 - Regression Model

\begin{tabular}{|c|c|c|c|c|c|c|c|}
\hline \multirow[b]{2}{*}{ Variables } & \multicolumn{2}{|c|}{ Unstandardized Coefficients } & \multirow{2}{*}{$\begin{array}{c}\text { Standardized Coefficients } \\
\text { Beta }\end{array}$} & & \multirow[b]{2}{*}{ ig. } & \multicolumn{2}{|c|}{ Collinearity statistic } \\
\hline & B & SE & & & & rance $^{\text {Tole }}$ & IF \\
\hline & -.125 & .238 & & .526 & 599 & & \\
\hline $\mathrm{Q}$ & .039 & .050 & .134 & 774 & 015 & .572 & .817 \\
\hline I & .155 & .042 & .172 & .724 & 000 & .623 & .534 \\
\hline $\mathrm{R}$ & .138 & .038 & .183 & .661 & 000 & 631 & .587 \\
\hline $\mathrm{X}$ & .393 & .045 & .438 & .752 & 000 & .619 & .642 \\
\hline $\mathrm{D}$ & .139 & .044 & .136 & .126 & 003 & .895 & .117 \\
\hline
\end{tabular}

Source: Prepared by the authors

Due to the result, all factor VIF is below $2.0(<2.0)$ result in no multi-collinearity occurring in the model. Significantly, the result asserts that (TQ) teaching facilitator quality, (BI) Business Interaction, (UR) University Reputation, (EX) Extracurricular activities, and (EP) Educational program are accepted to be statistically significant. As a result, these factors have a positive impact on BPharm student satisfaction with educational quality. Thus, the authors affirm $\mathrm{H} 1, \mathrm{H} 2, \mathrm{H} 3, \mathrm{H} 4, \mathrm{H} 5$. And, the relationship is presented in the regression model as follows:

$$
\mathrm{SS}=.438 * \mathrm{EX}+.183 * \mathrm{UR}+.172 * \mathrm{BI}+.136 * \mathrm{ED}+.134 * \mathrm{TQ}
$$




\section{Conclusion}

Today, pharmaceutical education quality has become a crucial concern in enhancing higher education. Additionally, educational quality is a cornerstone to the development of human resources in the pharmaceutical industry. By adapting HEdPERF, this study asserts the existence of the impactful relationship between BPharm student satisfaction various factors, including (1) Educational program, (2) University reputation, (3) Business interaction, (4) extracurricular activities, and (5) teaching facilitators quality. For academic contribution, this acknowledges crucially contributes to the development of knowledge in enhancing the BPharm student learning experience. In extensive provision, this study enriches the knowledge of higher education quality and general management. From a practical perspective, this study suggests higher education is the critical point for improvement, aiming to gain additional satisfaction from key stakeholders (i.e., students, parents, and employers). Despite the recognizable contribution, this study is limited by its research scopes that only focus on private universities in Ho Chi Minh City. And other factors might have an influence on students' satisfaction that is not included. Therefore, further studies are suggested focusing on the broader location in Vietnam. Ultimately, more factors are recommended to include in further research.

\section{REFERENCES}

ABDULLAH, F. The development of HEdPERF: a new measuring instrument of service quality for the higher education sector. International Journal of Consumer Studies, v. 30, n. 6, p. 569-581, 2006a.

ABDULLAH, F. Measuring service quality in higher education: HEdPERF versus SERVPERF. Marketing Intelligence \& Planning, 2v. 4, n. 1, p. 31-47, 2006 b.

ABUSHAM, A. A.; AL-HARTHY, N. A. Omani Students Involvement in Evaluating Their Pharmacy Program. International Journal of Clinical Pharmacology \&

Pharmacotherapy, v. 3, n. 136, p. 1-5, 2018.

AGA, M.; SAFAKLİ, O. V. An empirical investigation of service quality and customer satisfaction in professional accounting firms: evidence from north cyprus. Problems and Perspectives in Management, v. 5, n. 3, p. 84-98, 2007.

ANDERSON S. The state of the world's pharmacy: a portrait of the pharmacy profession. Journal of İnterprofessional Care, v. 16, n. 4, p. 391-404, 2002. 
BAKOBAN, R. A.; ALJARALLAH, S. A. Extracurricular activities and their effect on the student's grade point average: statistical study. Educational Research and Reviews, v. 10, n. 20, p. 2737-2744, 2015.

BASHETI, I. A. et al. Pharmacists' readiness to deal with the coronavirus pandemic: assessing awareness and perception of roles. Research in Social and Administrative Pharmacy, v. 17, n. 3, p. 514-522, 2021.

BOGUE, E. G. Quality assurance in higher education: the evolution of systems and design 1deals. New Directions for Institutional Research, v. 25, n. 3, p. 7-18, 1998.

BOGUE, E. G.; SAUNDERS, R. L. The evidence for quality. San Francisco: Jossey-Bass Inc., 1992

BRADY, K. M.; ROBERTSON, J. C. Searching for a consensus on the antecedent role of service quality and satisfaction: an exploratory cross-national study. Journal of Business Research, v. 51, n. 1, p. 53-60, 2001.

BROWN, A. L. Design experiments: theoretical and methodological challenges in creating complex interventions in classroom settings. Journal of the Learning Sciences, v. 2, n. 2, p. 141-178, 1992.

BRUBACHER, J. S. On the philosophy of higher education, San Francisco: Jossey-Bass, 1982.

BUSHELL, M. et al. Evaluation of vaccination training in pharmacy curriculum: preparing students for workforce needs. Pharmacy, v. 8, n. 3, p. 151, 2020.

CHEN, P. Y.; CUONG, B. M. An evaluation of student satisfaction of the joint master programs at Foreign Trade University in Vietnam. Journal of International Economics and Management, v. 20, n. 2, p. 75-88, 2020.

CHINH, N. D. Research and development of a set of criteria for evaluating education quality for Vietnamese UNIVERSITIES. In: CONFERENCE OF QUALITY ASSURANCE IN TRAINING IN VIETNAM, 2000, Da Lat. Proceedings [...]. Da Lat, Vietnam, 2000.

CHUA, C. Perception of quality in higher education. In: AUSTRALİAN UNIVERSITIES QUALITTY FORUM, 2004, Adelaide. Proceedings [...]. Adelaide, Australia, 2004.

CRONIN, J. J.; TAYLOR, S. A. Measuring service quality: A re-examination and extension. Journal of Marketing, v. 56, n. 3, p. 55-68, 1992.

DE RUYTER K. et al. Carry-over effects in the formation of satisfaction: the role of value in a hotel service delivery process In: SWARTZ, T. A.; BOWEN, D. E.; IACOBUCCI, D. (Eds.). Advances in services marketing and management. Greenwich, CT: JAI, 1992. v. 6, p. 61-78.

Dİ GREGORİO, L.; BEATON, F. Blogs in the modern foreign languages curriculum. A case study on the use of blogging as a pedagogic tool and a mode of assessment for modern foreign languages students. Higher Education Pedagogies, v. 4, n. 1, p. 406-421. 
DJAFRİ, F.; MEGUELLATİ, A.; OMAR, K. The impact of service quality, student satisfaction, and university reputation on student loyalty: a case study of international students in IIUM, Malaysia. Information Management and Business Review, v. 5, n. 2, p. 584-590, 2013.

DOAN, T. T. T. The Effect of Service Quality on Student Loyalty and Student Satisfaction: An Empirical Study of Universities in Vietnam. The Journal of Asian Finance, Economics and Business, v. 8, n. 8, p. 251-258, 2021.

GİAO, H. N. K.; LIEN, T. P. L. Factors affecting the quality of English education at the Center for Foreign Languages and Informatics, Banking University of Ho Chi Minh City. Industry and Trade, v. 7, p. 182-189, 2021.

GREEN, D. What is quality in higher education? Taylor \& Francis, 1994.

HARVEY, L.; GREEN, D. Defining quality. Assessment \& Evaluation in Higher Education, v. 18, n. 1, p. 9-34, 1993.

KAMVOUNIAS, P. Student as a customer and higher education as an industry: a review of the literature and the legal implications. Academy of Education Leadership Journal, v. 3, n. 1, p. $32-40,1999$.

KHALID, S. M.; ALİ, K. A. M.; MAKHBUL, Z. K. B. M. Assessing the effect of higher education service quality on job satisfaction among lecturers in premier polytechnics using HEDPERF model. LogForum, v. 15, n. 3, 2019.

KİEN, T. X. Evaluation of students' satisfaction toward education quality at Economic and Business Administration College: Thai Nguyen University. 2009. Thesis (Master in Education Management) - Institute of Education Quality Assurance, Hanoi National University, 2009.

KİLOVA, K. The Quality of the university education in bulgaria in the case of competition and dynamically developing educational system. In: IDİN, S. (Ed.). Research Highlights in Education and Science. 2020. p. 40-52.

KİRMIZİ, Ö. The influence of learner readiness on student satisfaction and academic achievement in an online program at higher education. Turkish Online Journal of Educational Technology-TOJET, v. 14, n. 1, p. 133-142, 2015.

KOTLER, P. Marketing Management Millennium Edition. New Jersey: Prentice-Hall, 2001.

LE, T. L. G. Structure of student satisfaction with higher education activities. 2015.

Dissertation (Doctoral) - Ha Noi National University, Vietnam, 2015.

LEE, K. Rethinking the accessibility of online higher education: a historical review. The Internet and Higher Education, v. 33, p. 15-23, 2017. 
LETCHER, D. W.; NEVES, J. S. Determinants of undergraduate business student satisfaction. Research in Higher Education Journal, v. 6, p. 1-26, 2010.

LIEN, P. T. Service quality and student satisfaction The case of University of Economics, Vietnam National University, Hanoi. VNU Journal of Science: Economics and Business, v. 32, n. 4, p. 81-89, 2016.

LONG, N. T. Using the multi-direction SERVPERF scale to measure the training quality through the evaluation of students at An Giang University. An Giang University Journal of Science, v. 27, 'p. 19-23, 2006.

LUONG, L. P. Using the SERVPERF scale model to study student satisfaction in teaching-learning. Nha Trang University, Khanh Hoa, Vietnam, 2011.

MALCOLM, F. Quality in higher education: an international perspective. In: GREEN, D. (Ed.). What is quality in higher education? London: Society for research into higher education, 1994. p. 101-111.

MYLREA, M. F.; GUPTA, T. S.; GLASS, B. D. Design and evaluation of a professional identity development program for pharmacy students. American Journal of Pharmaceutical Education, v. 83, n. 6, p. 1320-1327, 2019.

NECHEUKHINA, N. S. et al. Modern approaches to the educational process aimed at improving the quality of highly qualified personnel training. In: FORUM STRATEGIC PARTNERSHIP OF UNIVERSITIES AND ENTERPRISES OF HI-TECH BRANCHES, 6 ., 2017. Proceedings [...]. SPUE, 2017. p. 192-195. DOI:

https://doi.org/10.1109/IVForum.2017.8246089

NGOC, L. D. Building a culture of quality: Creating internal resources for training institutions to meet the requirements of the quality era. Center for Accreditation, Measurement and Evaluation of Education Quality (CAMEEQ), Hanoi, 2008.

NGUYEN, H. T. T.; DINNH, D. X.; NGUYEN, V. M. Knowledge, attitude and practices of community pharmacists regarding COVID-19: A paper-based survey in Vietnam. PloS One, v. 16, n. 7, e0255420, 2021.

OSMAN, A. R.; SAPUTRA, R. S. A pragmatic model of student satisfaction: a viewpoint of private higher education. Quality Assurance in Education, v. 27, n. 2, p. 142-165, 2019.

PARASURAMAN, A.; ZEITTHAML, V. A.; BERRY, L. SERVQUAL: A multiple-item scale for measuring consumer perceptions of service quality. Journal of Retailing, v. 64, n. 1, p. 12-40, 1988.

PHAM, L. et al. Does e-learning service quality influence e-learning student satisfaction and loyalty? Evidence from Vietnam. International Journal of Educational Technology in Higher Education, v. 16, n. 1, p. 1-26, 2019.

SAVAGE, N.; BİRCH, R.; NOUSSİ, E. Motivation of engineering students in higher education. Engineering Education, v. 6, n. 2, p. 39-46, 2011. 
SNIPES, R. L.; THOMSON, N. An empirical study of the factors underlying student service quality perceptions in higher education. Academy of Educational Leadership Journal, v. 3, n. 1, p. 39-57, 1999.

TANDİLASHVİLI, N. Factors influencing student satisfaction in higher education. The case of a Georgian state university. In: INTERNATIONAL RAIS CONFERENCE ON SOCIAAL, 13., 2019. Proceedings [...]. 2019.

TESSEMA, M. T.; READY, K.; YU, W. Factors affecting college students' satisfaction with major curriculum: Evidence from nine years of data. International Journal of Humanities and Social Science, v. 2, n. 2, p. 34-44, 2012.

TRAN, V. D.; LEWIS, R. The Effects of Jigsaw Learning on Students' Attitudes in a Vietnamese Higher Education Classroom. International Journal of Higher Education, v. 1, n. 2, p. 9-20, 2012.

TRUONG, H. V.; PHAM, C. H.; VO, N. H. Service Quality and Student Satisfaction in Private Colleges in Vietnam. International Journal of Financial Research, v. 7, n. 3, 2016.

TSE, D. K.; WILLTON, P. C. Models of Consumer Satisfaction Formation An Extension. Journal of Marketing Research, v. 25, n. 2, p. 204-212, 1988.

TURNER, D. A. Quality in higher education. Springer Science \& Business Media, 2012. v. 10 .

VİET, V. V. Factors affecting satisfaction with education service quality: A study from alumni of Nong Lam University in Ho Chi Minh City. Ho Chi Minh City University of Education Journal of Science, v. 14, n. 4, p. 171, 2017.

VO, T. H. et al. Pharmacy education in Vietnam. American Journal of Pharmaceutical Education, v. 77, n. 6, p. 114, 2013.

WANG, D.; SUN, Y.; JIANG, T. The Assessment of Higher Education Quality from the Perspective of Students through a Case Study Analysis. Frontiers of Education in China, v. 13, n. 2, p. 267-287, 2018.

ZEİTHAML, V. A.; BİTNER, M. J. Services Marketing: Integrating Customer Focus across the Firm. Irwin McGraw-Hill, 2000.

ZENG, X.; WANG, T. College Student Satisfaction with Online Learning during COVID19: A review and implications. International Journal of Multidisciplinary Perspectives in Higher Education, v. 6, n. 1, p. 182-195, 2021. 


\section{How to reference this article}

NGHIA, N. T.; SINGH, H. Factors influence student satisfaction in pharm education program: a case study in private universities in Vietnam. Revista online de Política e Gestão Educacional, Araraquara, v. 25, n. 3, p. 2611-2630, Sep./Dec. 2021. e-ISSN: 1519-9029. DOI: https://doi.org/10.22633/rpge.v25i3.15844

Submitted: $18 / 09 / 2021$

Required revisions: $16 / 10 / 2021$

Approved: $21 / 11 / 2021$

Published: 08/12/2021 